\title{
EFFORTS TO IMPROVEMENT LEARNING RESULTS THROUGH USE INTEGRATED PHYSICS LEARNING MULTIMEDIA IN THE SENIOR HIGH SCHOOL (SMA) 12 PEKANBARU
}

\author{
Muhammad Nasir ${ }^{* 1)}$, Budiawati ${ }^{2)}$ \\ ${ }^{1)}$ Physics Education, University of Riau \\ ${ }^{2)}$ Senior High School (SMA)12 Pekanbaru \\ e-mail: muhammad.nasir@lecturer.unri.ac.id \\ budiawatizarman@yahoo.com
}

\begin{abstract}
This research is a classroom action research that aims to improve student learning outcomes by using integrated multimedia learning physics for senior high school or equivalent. This research was conducted at the senior high school (SMA) 12 Pekanbaru. The subjects in this study were students of class X IPA 1 with 36 students consisting of 16 male students and 20 female students. The study was conducted in two cycles and consisted of 8 meetings with the details of the first cycle consisting of three meetings and three times quiz and one daily test (UH) and the second cycle consisted of four meetings consisting of three meetings and three times a and one dayly test. Each cycle is analyzed and feedback and repairs are needed. Based on the results of the study, it was found that there was an increase in individual completeness in the 1 st cycle. $40.41 \%$ at quis-1, $51.65 \%$ at quis-2 and $90.81 \%$ at quis-3. Likewise, the second cycle. 80.25 in quiz-1, $85.75 \%$ in quis-2 and $90.00 \%$ in quis-3. Based on these results it was found that the increase in individual completeness in the 2nd cycle was higher and more stable. This shows that the results of individual completeness during learning both cycle-1 and cycle-2 have increased, but the increase in cycle-2 is more linear. These results indicate that learning using integrated multimedia can improve student physics learning outcomes.
\end{abstract}

Keywords: Integrated Multimedia, Student Physics Learning Results, Classroom Action Research

\section{UPAYA MENINGKATKAN HASIL BELAJAR MELALUI PENGGUNAAN MULTIMEDIA PEMBELAJARAN FISIKA TERINTEGRASI DI SEKOLAH MENENGAH ATAS (SMA) NEGERI 12 PEKANBARU}

\author{
Muhammad Nasir ${ }^{* 1}$, Budiawati $^{2)}$ \\ ${ }^{1)}$ Pendidikan Fisika,Universitas Riau \\ ${ }^{2)}$ Sekolah Menengah Atas (SMA)Negeri 12 Pekanbaru
}

\begin{abstract}
Abstrak
Penelitian ini adalah penelitian tindakan kelas yang bertujuan untuk meningkatkan hasil belajar peserta didik dengan menggunakan multimedia terintegrasi dalam pembelajraan fisika untuk SMA sederajad. Penelitian ini dilaksanakan di Sekolah Mengah Atas Negeri 12 Pekanbaru. Subjek dalam penelitian ini adalah peserta didik kelas X IPA 1 dengan 36 peserta didik yang terdiri dari 16 peserta didik laki-laki dan 20 peserta didik perempuan. Penelitian dilaksanakan dua siklus dengan 8 kali pertemuan. Dengan rincian siklus-1 terdiri 3 kali petemuan dan tiga kali quis satu kali ulangan harian dan siklus-2 terdiri atas 4 kali pertemuan dengan terdiri 3 kali petemuan dan tiga kali quis satu kali ulangan harian. Setiap siklus dilakukan analisis dan umpan balik serta perbaikan yang diperlukan. Berdasarkan hasil penelitian didapat bahwa terjadi peningkatan
\end{abstract}


ketuntasan individu pada siklus-1. 40,41\% pada quis-1, 51,65\% pada quis-2 dan 90,81\% pada quis-3 Demikian juga halnya pada siklus-2. 80,25 pada quis-1, 85,75\% pada quis-2 dan 90,00\% pada quis-3. Berdasarkan hasil ini didapat bahwa peningkatan ketuntasan individu pada siklus-2 lebih tinggi dan lebih stabil. Ini menunjukkan bahwa hasil ketuntasan individu selama pembelajaran baik siklus-1 maupun siklus-2 mengalami peningkatan, namun peningkatan pada siklus-2 lebih linier. Hasil ini menunjukkan bahwa pembelajaran dengan menggunakan multimedia terintegrasi dapat meningkatan hasil belajar fisika peserta didik.

Kata kunci: multimedia terintegrasi, hasil belajar fisika, penelitan tindakan kelas,

\section{Pendahuluan}

Penelitian ini dilatarbelakangi karena adanya permasalahan dalam pembelajaran di kelas X di Sekolah Menengah Negeri 12 Pekanbaru, yaitu kurang maksimalnya hasil belajar peserta didik pada mata pelajaran Fisika ini ditunjukkan hanya $45 \%$ peserta didik yang memenuhi nilai sesuai KKM. Ketidaktuntasan sebahagian dari peserta didik antara lain disebabkan karena guru cenderung menggunakan metode ceramah dan tanya jawab serta jarang menggunakan beragam media visualisasi dan model pembelajaran. Akibatnya pembelajaran kurang aktif, tidak bervariasi, terkesan monoton, dan membosankan. Dampak negatif adalah kemampuan peserta didik dalam pembelajaran Fisika tidak memberikan hasil yang memuaskan.

Fisika sebagai salah satu pelajaran dianggap penting namun fenomenanya fisika merupakan salah satu pelajaran yang dianggap sebagai pelajaran yang sulit (Muhammad Nasir, 2018). Terdapat tiga penyebab utama peserta didik kesulitan mempelajari fisika (Erinosho, 2013) yaitu faktor guru, faktor alam dan faktor kurikulum. Peserta didik kesulitan memahami pelajaran fisika yang ditentukan oleh kurikulum, yang hanya memberikan contoh matematis saja dan sangat kurang memberikan contoh yang nyata.

Fisika merupakan suatu ilmu yang empiris. Pernyataan-pernyataan fisika harus didukung oleh hasil-hasil eksperimen. Hasil eksperimen digunakan untuk eksplorasi informasi-informasi membentuk teori lebih lanjut (Mayub, 2005), Namun menurut (Novian Wahyu Setiabudi, 2005) penggunaan laboratorium terbatas karena kurangnya alatalat labor yang tersedia. Menurut Muhammad Nasir (2017a), MJA Rahman et al., (2014) maka dibutuhkannya media yang dapat membantu peserta didik memahami pembelajaran fisika. Sementara media pem- belajaran yang tersedia sebelumnya masih terkesan monoton Muhammad Nasir (2017b), sehingga minat belajar peserta didik pada pelajaran fisika kurang tinggi. Hal tersebut juga menyebabkan materi fisika sulit diterima oleh peserta didik karena minimnya media pembelajaran interaktif yang tersedia.

Latief (2010) menuturkan bahwa, proses pembelajaran yang kurang menarik membuat daya serap peserta didik pada pelajaran tidak optimal. Hasil penelitian "Potret Profesionalitas guru kota Yogyakarta dalam kegiatan belajar mengajar" yang dilakukan jaringan penelitian pendidikan kota Yogyakarta (JP2KY) awal tahun 2010 menunjukkan, 75\% guru peserta penelitian belum menggunakan media pembelajaran dalam mengajar. Hal tersebut sesuai dengan hasil penelitian Fitra Suci Arista (2013) bahwa faktor eksternal yang cukup berpengaruh pada kesulitan belajar fisika peserta didik pada aspek metode guru tepatnya pada indikator penggunaan media pembelajaran. Penggunaan media pembelajaran oleh guru ini merupakan indikator yang dianggap paling sulit dalam belajar fisika bagi peserta didik. Artinya, secara umum guru SMA Negeri Pekanbaru belum menggunakan media pembelajaran yang seharusnya dapat membantu guru dalam menjelaskan konsepkonsep fisika kepada peserta didik.

Menurut Hamdani at al., (2017) bahwa sebenarnya para guru telah banyak mengenal berbagai macam jenis media pembelajaran, namun kurang memiliki waktu untuk mendalami salah satu perangkat dalam pembuatan media pembelajaran. Sebagai akibatnya, guru lebih nyaman dengan hanya mengunduh dari internet.

Sintia at al., (2014) menyatakan bahwa guru telah menggunakan media berupa powerpoint, tetapi media yang digunakan masih kurang menarik. Hal ini disebabkan karena tampilan media tersebut kurang dapat 
memotivasi peserta didik untuk mengikuti proses pembelajaran, kurang adanya gambar atau animasi, tidak terdapat instrument musik yang mengiringi media, serta tidak terdapat soal evaluasi yang interaktif.

Guru sering lalai menyiapkan perangkat pembelajaran (Riyan Pradnyana, 2016) Persiapan mengajar tentunya sudah sering disiapkan oleh guru sebelum mengajar. Tetapi, tidak sedikit guru yang kadang enggan membuat persiapan mengajar. Hal tersebut dimungkinkan karena kesibukan di rumah atau masalah tertentu. Guru juga sering lupa membawa perangkat pembelajaran saat mengajar padahal mereka memiliki ataupun telah menyiapkannya dengan baik, hal ini berdasarkan hasil observasi Tomi Tridaya Putra et al., (2010). Sedangkan perangkat pembelajaran lain seperti silabus, RPP dan yang lainnya tidak terlihat dibawa oleh guru.

Oemar Hamalik mengatakan, dalam Said Alwi (2017) guru bertanggung jawab melaksanakan kegiatan pendidikan di sekolah, artinya memberikan bimbingan dan pengajaran kepada peserta didik. Tanggung jawab ini direalisasikan dalam bentuk melaksanakan pembinaan kurikulum, menuntun para peserta didik belajar, membina pribadi, watak dan jasmaniah peserta didik, menganalisis kesulitan belajar serta menilai kemajuan belajar para peserta didik.

Peran guru menjadi kunci keberhasilan dalam mengembangkan misi pendidikan dan pengajaran di sekolah selain bertanggung jawab untuk mengatur, mengarahkan dan menciptakan suasana kondusif yang mendorong peserta didik untuk melaksanakan kegiatan di kelas. Menurut Abdul Majid (2011) mengingat sangat kompleksnya tujuan pendidikan, maka betapa besar dan beratnya tugas seorang pendidik dalam menciptakan kualitas hasil pendidikan. Sementara H.M. Arifin, (2000), menyatakan keterampilan guru dalam mengajar merupakan faktor yang paling dominan dalam upaya menstransfer ilmu pengetahuan kepada peserta didik, karena hal itu dapat mengatasi kebosanan peserta didik dalam belajar, sehingga tercipta suasana belajar yang kreatif dan menyenangkan selain itu Azhar Arsyad (2011) menyatakan penggunaan media pembelajaran dalam proses belajar mengajar dapat membangkitkan keinginan dan minat baru, membangkitkan motivasi dan rangsangan kegiatan belajar, bahkan mampu membawa pengaruh psikologis pada peserta didik. Berdasarkan paparan yang telah diuraikan, maka perlu dibangun multimedia pembalajaran yang menarik yang dapat memvisualisasikan konsep yang abstrak menjadi lebih konkrit yang terintegrasi dengan perangkat pembelajaran.

\section{Bahan dan Metode}

Penelitian ini menggunakan model penelitian tindakan kelas Kemmis \& McTaggart. Menurut Chih-Hsien (2018) bahwa rancangan Kemmis \& Taggart dapat mencakup sejumlah siklus, masing-masing terdiri dari tahap-tahap: perencanaan (plan), pelaksanaan dan pengamatan (act \& observe), dan refleksi (reflect). Tahapan-tahapan ini berlangsung secara berulang-ulang, sampai tujuan penelitian tercapai. Seperti pada Gambar 1.

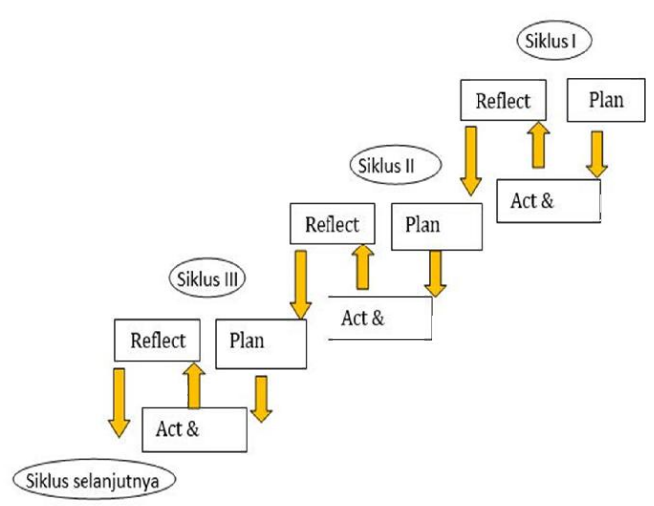

Gambar 1. Model penelitian tindakan kelas Kemmis \& McTaggart.

Subjek dalam penelitian ini adalah peserta didik kelas X IPA 1 SMA Negeri 12 Pekanbaru, tahun pelajaran 2018/2019 yang terdiri dari 16 orang laki-laki dan 20 orang perempuan. Adapun langkah-langkah kerja dalam penelitian adalah sebagai berikut:

1. Membuat skenario pembelajaran.

2. Mempersiapkan fasilitas dan sarana pendukung.

3. Melakukan tindakan pertama (siklus I).

4. Melakukan analisis data. 
5. Melakukan refleksi terhadap pembelajaran tindakan pertama (siklus I).

6. Memperbaiki skenario pembelajaran berdasarkan hasil refleksi.

7. Pelaksanaan tindakan kelas kedua (siklus II), dalam hal ini dilakukan penekanan keadaan kelas pada kelas yang berbeda.

8. Menganalisis data (siklus II).

9. Melakukan refle ksi (siklus II).

10. Pelaksanaan tindakan kelas ketiga (siklus III).

11. Melakukan refleksi (siklus III).

12. Menganalisis data.

Instrument yang digunakan dalam penelitian ini adalah lembar tes, lembar pengamatan (observasi) aktivitas guru dan aktivitas peserta didik. Adapun teknik pengumpulan data yaitu daya serap ketuntasan individu $(\mathrm{N})$ dan ketuntasan belajar klasikal (KBK) menurut persamaan 1 dan 2 .

$$
\mathrm{N}=\frac{\text { Skor perolehan peserta didik }}{\text { Skor Maksimal }} \times 100
$$

dan

$$
\mathrm{KBK}=\frac{\text { Jumlah peserta didik tuntas }}{\text { Jumlah seluruh siswa }} \times 100 \%
$$

Selanjutnya untuk ketuntasan memenuhi persamaan 3.

$$
\text { Ketuntasan }=\mathrm{N} \geq \mathrm{KKM}
$$

\section{Hasil dan Pembahasan}

Hasil pembelajaran ini merupakan hasil yang diperoleh melalui pembelajaran yang menggunakan multimedia pembelajaran terintegrasi yang dapat memberikan gambaran visual tentang konsep vektor, gerak dan gerak melingkar.

Multimedia ini dilengkapi dengan efek bunyi dan visualisasi dari konsep vektor dan gerak yang bersifat abstrak sehingga menjadikan konsep yang abstrak itu menjadi lebih konkrit.
Hasil multimedia itu dapat dilihat melalui Gambar 2. sampai dengan Gambar 5.

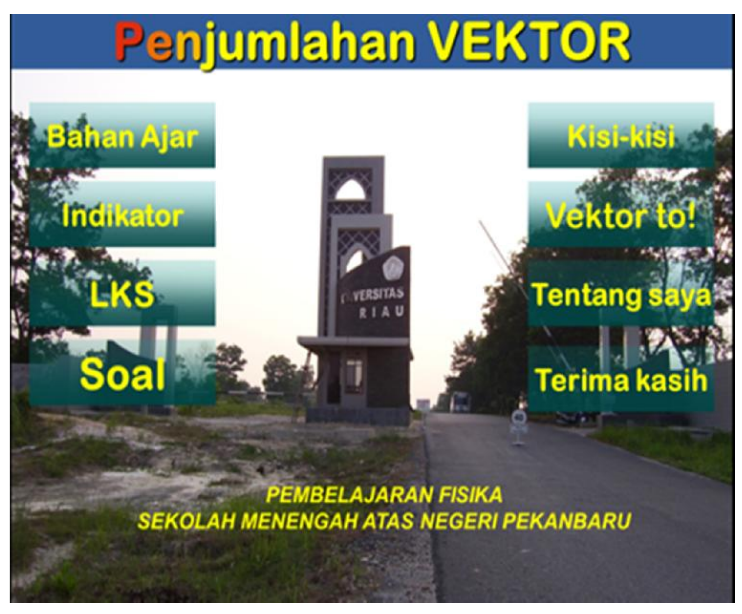

Gambar 2. Menu utama.

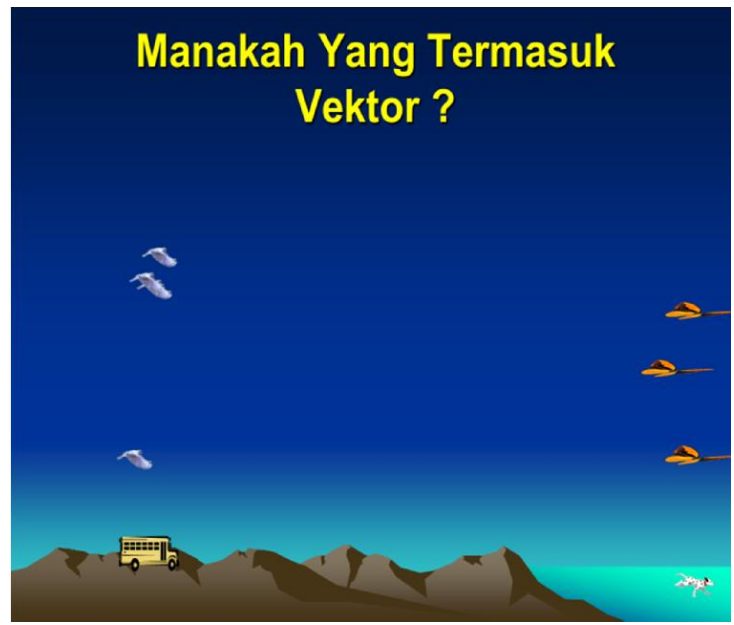

Gambar 3. Sub menu material.

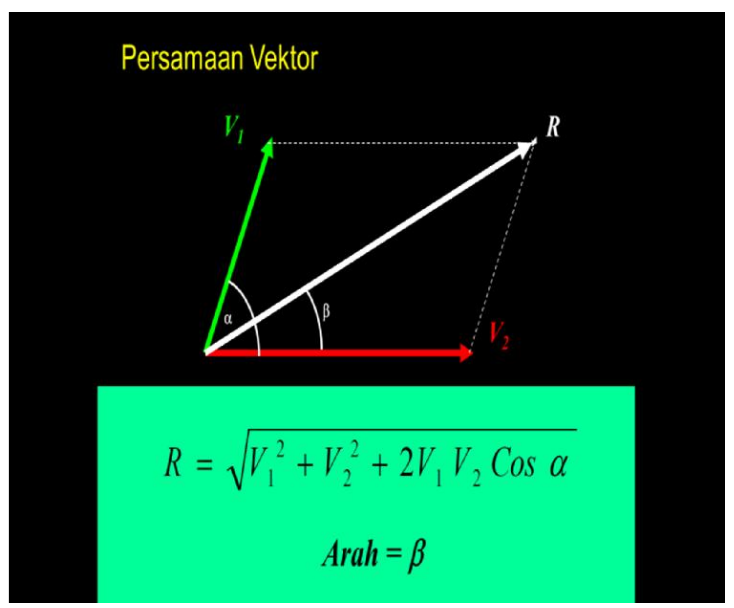


Gambar 4. Sub menu student work sheet.

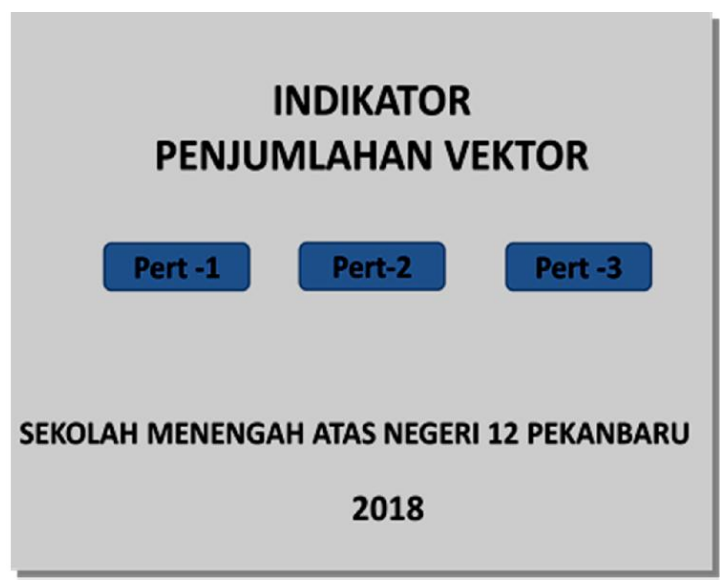

Gambar 6. Sub menu evaluation.

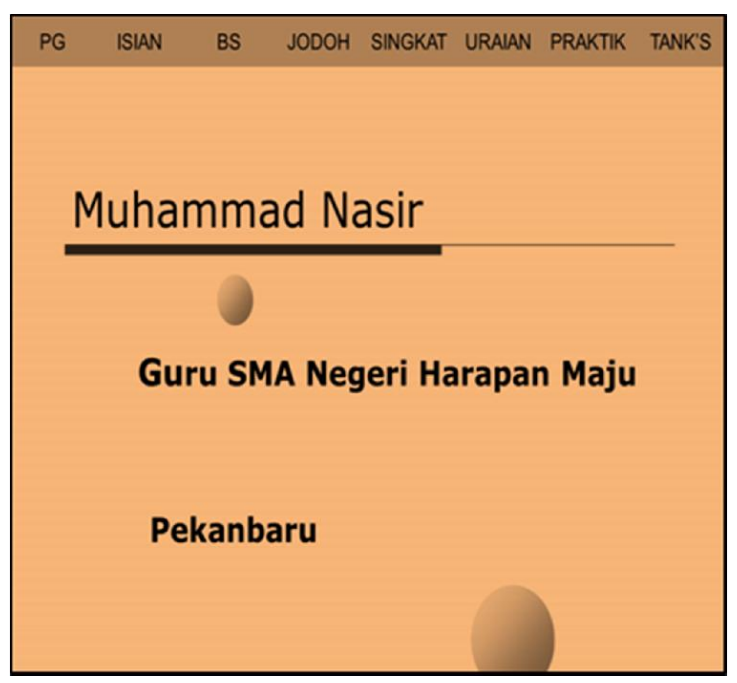

Gambar 6. Kompetensi pembelajaran.

Gambar 2. menunjukkan hasil tampilan multimedia menu utama, dimana dalam menu utama itu terdapat bahan ajar, kompetensi atau indikator, LKPD atau student work sheet, soal latihan dan pembahasan serta soal untuk evaluasi, kisi-kisi pembelajaran, animasi khusus vektor (vektor to !), tentang saya (tentang guru) dan ucapan terimakasih, seperti yang dapat dilihat seperti pada Gambar 2. Dimana pada setiap menu utama berisi sub menu sesuai dengan menu utama itu.

\section{Hasil Belajar.}

Pembelajaran dilaksanakan dengan 2 siklus dan masing-masing siklus 3 kali pertemuan dengan materi KD.3.3 dan KD 4.3 Tiap pertemuan diberikan quis pada akhir pertemuan dengan mengalokasikan waktu 10 menit. Quis diberikan dengan mengambil bentuk soal objektip. Pada pertemuan ke-2 dilakasanakan dengan mengacu kepada perbaikan hasil quis-1 pada akhir pertemuan ke-1. Pada pertemuan ke-3 dilakasanakan dengan mengacu kepada hasil quis-2 pada pertemuan ke-2. Pada akhir pertemuan ke-3 setelah quis-3 disampaikan kepada peserta didik bahwa pertemuan ke-4 akan dilaksanakan evaluasi berupa ujian harian atau UH-1.

Setelah UH-1 maka pada pertemuan ke-5 dilaksanakan pembelajaran dengan mengacu kepada hasil analisis pada Hasil Ujian harian I. Pada KD-3.4 dan KD 4.4. pada akhir pertemuan ke-5 dilaksanakan quis-4 kemudian dianalisis dan dilaksanakan perbaikan pada pertemuan ke6 dan pada petemuan ke-6 dilaksanakan quis-5, kemudian dianalisis dan dilaksanakan pembelajaran pada pertemuan ke-7 dan quis ke-6. Pada akhir pertemuan ke-7 disampaikan bahwa pertemuan ke-8 akan dilaksanakan evaluasi dalam bentuk ujian harian ke-2. Dengan demikian dalam penelitian ini terdapat 2 siklus, 8 kali pertemuan dan 6 kali quis. Hasil masing masing dapat dilihat pada Tabel 1 dan Tabel 2.

Tabel 1. Hasil belajar untuk siklus-1

\begin{tabular}{lcccc}
\hline Siklus & \multicolumn{4}{c}{ I } \\
\hline Rata-rata & $\begin{array}{c}\text { Quis-1 } \\
79,17\end{array}$ & $\begin{array}{r}\text { Quis-2 } \\
80,25\end{array}$ & $\begin{array}{c}\text { Quis-3 } \\
89,08\end{array}$ & $\begin{array}{l}\text { UH-1 } \\
85.88\end{array}$ \\
\hline $\begin{array}{l}\text { Ketuntasan } \\
\text { Individu }\end{array}$ & $40,41 \%$ & $51,65 \%$ & $90,81 \%$ & $81,85 \%$ \\
\hline $\begin{array}{l}\text { Ketuntasan } \\
\text { Klasikal }\end{array}$ & TT & $\mathrm{T}$ & $\mathrm{T}$ & $\mathrm{T}$ \\
\hline
\end{tabular}

Tabel 2. Hasil belajar pada siklus II

\begin{tabular}{lcccc}
\hline Siklus & \multicolumn{4}{c}{ II } \\
\hline Rata-rata & Quis-1 & Quis-2 & Quis-3 & UH-2 \\
& 81,25 & 87,87 & 91,8 & 90,15 \\
\hline $\begin{array}{l}\text { Ketuntasan } \\
\text { Individu }\end{array}$ & $80,25 \%$ & $85,75 \%$ & $90,00 \%$ & $95.66 \%$ \\
\hline $\begin{array}{l}\text { Ketuntasan } \\
\text { Klasikal }\end{array}$ & $\mathrm{T}$ & $\mathrm{T}$ & $\mathrm{T}$ & $\mathrm{T}$ \\
\hline
\end{tabular}




\section{Hasil siklus I}

Berdasarkan Tabel 1 dapat dilihat bahwa pada siklus I hasil dari quis cenderung meningkat walaupun hasil kuis-1 hanya $40 \%$ yang tuntas, namun menunjukkan kenaikan siklus I. Hal ini dapat dipahami bahwa perlu pembiasaan dalam pembelajaran dengan multimedia terintegrasi. Namun hasil quis untuk selanjutnya menunjukkan hasil yang menggembirakan dan hasil ulangan hariannya 85,88 dengan ketuntasaan individu 81,85 . Untuk melihat kecenderngan perkembangan kuis pada siklus I seperti yang terlihat pada Gambar 7.

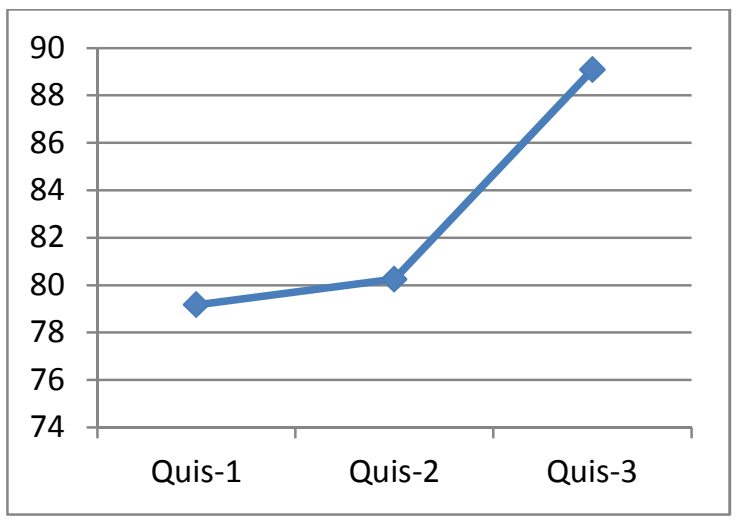

Gambar 7. Grafik trend perkembangan nilai quis pada siklus ke-1.

Berdasarkan pada Gambar 7. dapat kita lihat bahwa kecenderungan (trend) nilai quis pada siklus-1 cenderung naik. Hasil ini menunjukkan bahwa peserta didik sudah nyaman dengan menggunakan multimedia terintegrasi ini. Sedangkan apabila kita melihat trend hasil ketuntasan individu selama siklus-1 dapat kita lihat seperti pada Gambar 8.

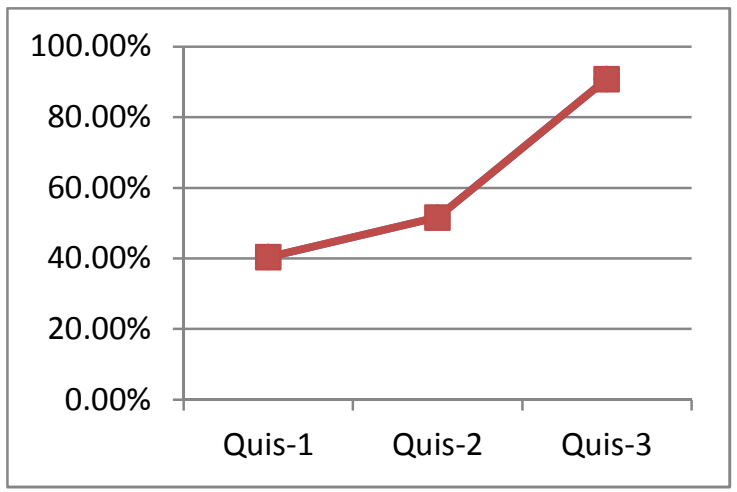

Gambar 8. Grafik trend ketuntasan individu pada siklus-1.
Berdasarkan Gambar 8. dapat kita lihat bahwa kecenderungan hasil ketuntasan belajar individu pada siklus-1 cenderung meningkat. Hasil ini menunjukkan bahwa peserta didik sudah nyaman dan sudah terbiasa menggunakan multimedia terintegrasi sebagai media pembelajaran.

\section{Hasil siklus II}

Berdasarkan Tabel 2. dapat dilihat bahwa pada siklus II hasil dari quis meningkat namun untuk setiap quis pada siklus II sudah tuntas walaupun untuk quis-4 sudah diperoleh 81,25 , namun menunjukkan kenaikan pada siklus II. Hal ini dapat dipahami bahwa perlu pembiasaan dalam pembelajaran dengan multimedia terintegrasi. Untuk pertemuan pada siklus II agak rendah namun ini dapat dipahami karena ini merupakan materi baru. Secara keseluruhan hasil belajar menunjukkan hasil yang menggembirakan dan hasil ulangan hariannya 90,15 dengan ketuntasaan individu sebesar 95,66.

Untuk melihat trend hasil quis selama siklus-1I dapat kita lihat seperti pada Gambar 9.

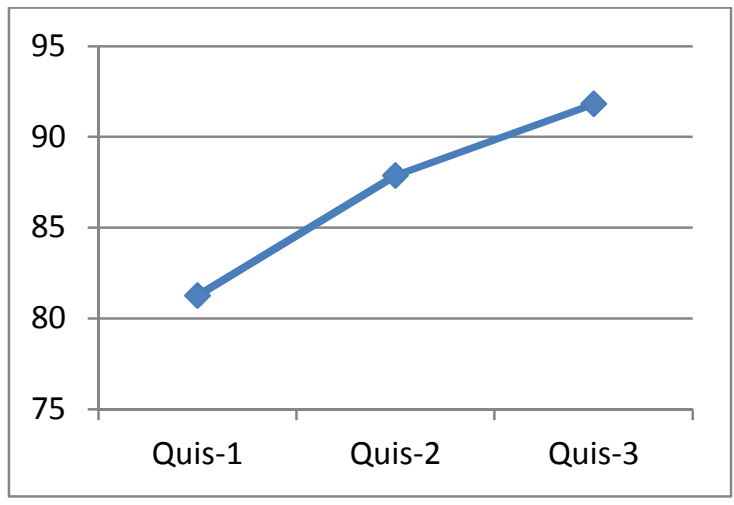

Gambar 9. Grafik trend hasil quis pada siklus-2.

Berdasarkan Gambar 9 dapat dilihat bahwa kecenderungan (trend) nilai quis pada siklus-1I cenderung naik. Hasil ini menunjukkan bahwa peserta didik sudah nyaman dengan pembelajaran yang menggunakan mulmedia terintegrasi ini. Sedangkan apabila kita melihat trend hasil ketuntasan individu selama siklus1I dapat kita lihat seperti pada Gambar 10. 


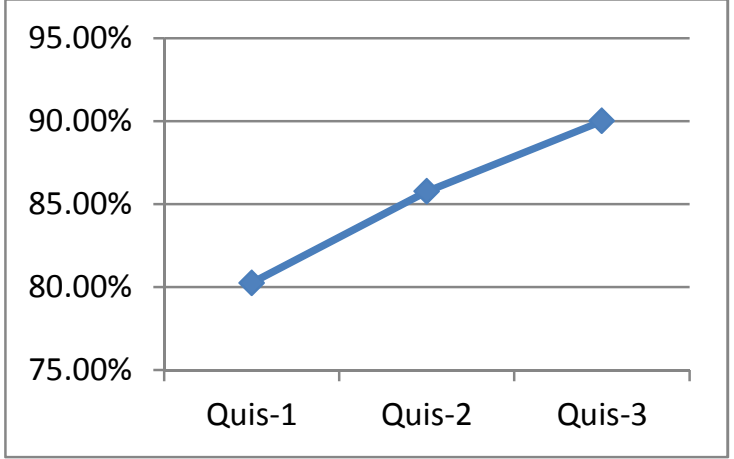

Gambar 10. Grafik kecenderungan hasil ketuntas individu pada siklus-2.

Berdasarkan Gambar 10 dapat kita lihat bahwa kecenderungan hasil ketuntasan belajar individu pada siklus-1I cenderung meningkat. Hasil ini menunjukkan bahwa peserta didik sudah nyaman dan sudah terbiasa menggunakan multimedia terintegrasi sebagai media pembelajaran.

\section{Hasil Keseluruhan Siklus}

Secara keseluruhan hasil pembelajaran ini dapat dilihat dengan membandingkan hasil quis selama siklus-1 dan hasil quis selama siklus-2 dapat kita lihat seperti pada Gambar 11.

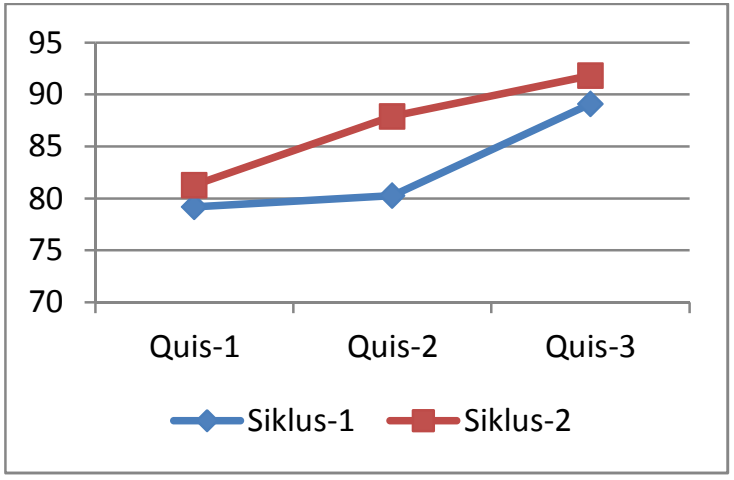

Gambar 11. Perbandingan perkembangan kemajuan hasil quis selama siklus-1 dan siklus-2.

Berdasarkan pada Gambar 11. dapat kita lihat perbandingan progress atau perkembangan hasil belajar berdasarkan hasil quis yang dilaksanakan selama siklus-1 dan siklus2. Dari gambar tersebut dapat kita lihat bahwa pada siklus 2 selain capaian pembelajran berdasarkan nilai quis lebih tinggi, namun yang terlihat ialah bahwa tingkat kecenderungan hasil belajarnya berdasarkan nilai quis itu, menunjukkan kecenderungan lebih linier artinya peningkatan semakin besar ketika siklus-1I dilaksanakan. Fakta ini menunjukkan bahwa pembelajran dengan menggunakan multimedia terintegrasi dapat meningkatkan hasil belajar.

Untuk dapat melihat peningkatan hasil belajar yang lebih jelas lagi mari kita lihat melalui hasil belajar yang dievaluasi berdasarkan hasil evaluasi UH-1 dan UH-2 yang dilaksanakan setelah siklus-1 berakhir untuk UH-1 dan saat siklus-2 berakhir untuk UH-2. Hasil ini dapat dilihat seperti pada Gambar 12.

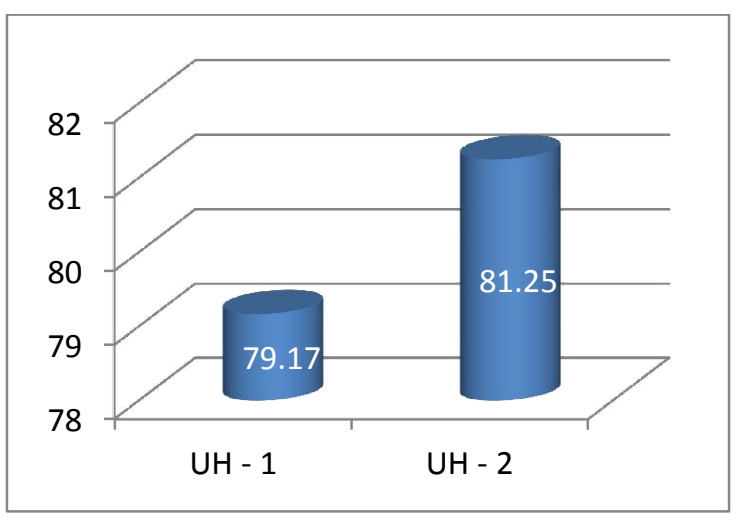

Gambar.12 Hasil perkembangan nilai UH-1 dan UH-2 pada siklus-1 dan siklus-2.

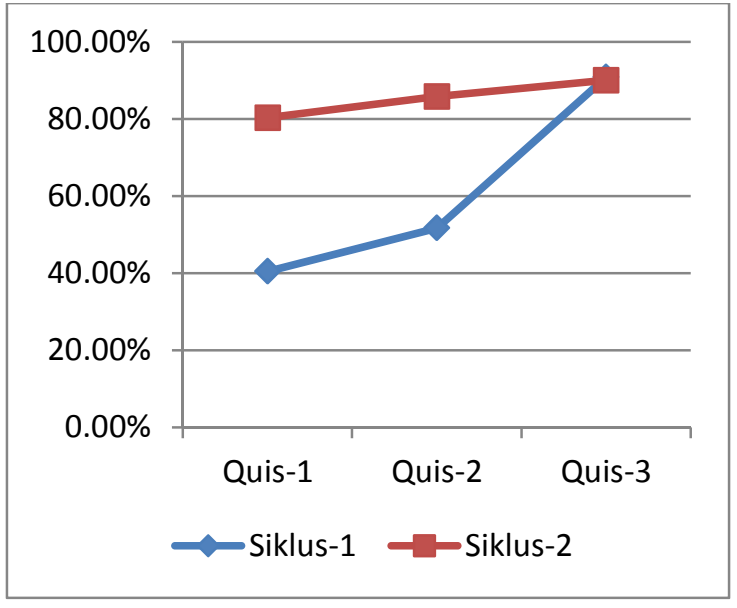

Gambar 13. Ketuntasan Individu siklus-1 dan siklus-2 pada capaian nilai quis. 
Berdasarkan Gambar 12. dapat kita lihat bahwa capaian nilai UH-1 dan UH-2 selama siklus-1 dan siklus-2 menunjukkan hasil peningkatan. Hasil ini memperkuat bahwa hasil belajar pada siklus-1 lebih baik dari pada siklus-2 ini dapat diartikan bahwa terjadi peningkatan hasil belajar dari siklus-1 ke siklus-2. Apabila kita ingin melihat hasil belajar secara individu, maka kita dapat melihat hasil belajar berdasarkan ketuntasan individu selama siklus-1 dan siklus-2 seperti pada grafik pada Gambar 13.

Berdasarkan Gambar 13. dapat kita lihat bahwa terjadi peningkatan ketuntasan individu pada siklus-1. Demikian juga halnya pada siklus-2. Namun bila kita perhatikan pada grafik nampaklah bahwa peningkatan ketuntasan individu pada siklus-2 lebih tajam dan lebih linier. Ini menunjukkan bahwa hasil ketuntasan individu selama pembelajaran baik siklus-1 maupun siklus-2 mengalami peningkatan, namun peningkatan pada siklus-2 lebih linier. Hasil ini menunjukkan bahwa pembelajaran dengan menggunakan multimedia terintegrasi dapat meningkatan hasil belajar fisika peserta didik.

\section{Kesimpulan dan Saran}

Berdasarkan data hasil peneltian dan pembahasan yang telah dilakukan, maka dapat disimpulkan bahwa pembelajaran dengan menggunakan multimedia terintegrasi dapat meningkatkan hasil belajar fisika peserta didik.

Berdasarkan kesimpulan tersebut, maka dapat disarankan bahwa pembelajaran menggunakan multimedia terintegrasi perlu pembiasaan dalam pembelajaran, dengan demikian perlu latihan dan pembiasaan dalam penggunakan multimedia bagi peserta didik agar terjadi peningkatan hasil belajar.

\section{Daftar Pustaka}

Chih-Hsien Huang. 2018. Investigating Engineering Students' Mathematical Modeling Competency. American Journal of Educational Research, 6 (12), 1668-1672. doi: 10.12691/ education-6-12-12).
Erinosho, S. Y., 2013. How Do Student Percieve the Difficulty of Physics in Secondary School? An Exploratory.

Fitra Suci Arista, 2013. Analisis Kesulitan Belajar Fisika Peserta didik Sekolah Menengah Atas Negeri Se-Kota Pekanbaru. Universitas Riau. Pekanbaru.

Hermann, M., Pentek, T., \& Otto, B., 2016. Design Principles for Industrie 4.0 Scenarios. Presented at the 49th Hawaiian International Conference on Systems Science.

Hamdani., Reni Marlina, 2017. Analisis Tingkat Pengetahuan Guru Sekolah Menengah Tentang Media Pembelajaran Interaktif Dengan Perangkat Lunak Ispring Presenter. http://pipt.untan.ac.id/ index.php/seminarpipt/pipt2017/paper/vi ewFile/31/115 (diakses pada tanggal 28 Maret 2018).

Kramarski, B., \& Zeichner, O., 2001. Using Technology to Enhance Mathematical Reasoning: Effects of Feedback and Self-Regulation Learning. Educational Media International, 38 (2/3), 77-82.

Latief, 2010. "Ah, Pengajaran Guru Masih Membosankan!". Kompas (online). https://edukasi.kompas.com/read/2010/0 5/25/11123511/Ah.Pengajaran.Guru.Ma sih.Membosankan (diakses pada 20 Maret 2018).

Mayub, Afrizal, 2005. e-Learning Fisika Berbasis Macromedia Flash MX. Penerbit Graha Ilmu. Yogyakarta.

Muhammad, Yahya, 2018. Era Industri 4.0: Tantangan Dan Peluang Perkembangan Pendidikan Kejuruan Indonesia, Inauguration Speech for Permanent Professor in the Field of Vocational Education Science, Faculty of Engineering, Makassar State University.

Muhammad Nasir, Rizo., B.P., Riwayani, 2018. Design and Development of Physics Learning Media of Three Dimensional Animation Using Blender Applications on Atomic Core Material.

Muhammad Nasir, 2017a. Design and Empirical Analysis Visualization Motion and Vector Analysis Program as Interactive Multimedia Physics Learning at Senior High School, Pekanbaru, Indonesia.. Applied Science and Technology, 1 (1), 240-247. 
Muhammad Nasir, 2017b. Development and Evaluation of Virtual Physics Laboratory As Multimedia Learning Physics On Senior High Schools (SMA) Pekanbaru. Applied Science and Technology 1 (1), 565-572.

MJA Rahman, MAH Ismail, M Nasir., 2014. Development and Evaluation of the Effectiveness of Computer-Assisted Physics Instruction. International Education Studies, 7 (13), 14.

Novian Wahyu Setiabudi, 2005. Pengembangan Media Pembelajaran Berbasis Multimedia untuk Mata Pelajaran Fisika Bahasan Kinematika Gerak Lurus. Fakultas Teknik Universitas Negeri Semarang. Semarang.

Riyan Pradnyana, 2016. Pentingnya Persiapan Mengajar dan Jangan Diabaikan. Riyanpedia.com (online).

http://www.riyanpedia.com/2016/11/pen tingnya-persiapan-mengajar-dan-jangandiabaikan.html (diakses pada 20 Maret 2018).
Sintia Y., Eko W., 2014. "Pengembangan Media Pembelajaran Berbasis

Multimedia Interaktif pada Mata Pelajaran Ekonomi Materi Jurnal Penyesuaian Perusahaan Jasa." Jurnal Pendidikan Akuntansi, 2.2 (2014): 1-9.

Tomi Tridaya Putra, Delvia Afriliani \& Esa Putri Dinanti, 2010. Laporan Observasi: Penggunaan Perangkat Pembelajaran Matematika di SMP Negeri 12 Padang. Universitas Negeri Padang (online). https://triatra.wordpress.com/2010/12/ 11/laporan-observasi-penggunaanperangkat-pembelajaran-matem atikadismp-negeri-12-padang/ (diakses pada tanggal 28 Maret 2018).

Richard Owino Ongowo, \& Francis Chisakwa Indoshi, 2013. Science Process Skills in the Kenya Certificate of Secondary Education Biology Practical Examinations. Scientifik Research An Academic Publisher, 4 (11), pp.713-717. 